\title{
NUTNOST CHRÁNIT SOUKROMÍ ANEB NIČIVÝ DOPAD INTERNETU PO TRAGICKÝCH UDÁLOSTECH NA RODINU A POZŮSTALÉ
}

\author{
LENKA VLÁŠKOVÁ
}

\begin{abstract}
Příspěvek si klade za cíl sdělit poznatky z praxe o zraňujícím dopadu na psychiku rodiny a pozůstalých po tragických událostech, obětech trestných činů a mimořádných neštěstích, pokud jsou informace o události zveřejňovány na sociálních sítích a zpravodajských portálech na internetu zejména bezprostředně po vzniklé situaci. Nejde o to vyjmenovat všechny reakce a možnosti chování, ale identifikovat klíčové faktory v procesu sekundární viktimizace a ukázat jiný rámec pohledu na zveřejňování informací o tragických událostech v širších souvislostech. Žijeme v době, kdy je velmi snadné cokoli zdokumentovat, vyfotit, natočit a uveřejnit na sociálních sítích. A ukazuje se, jak rychle pracují média ve vztahu k tragickým událostem. Často se stává, že se na internetu objeví fotografie z místa tragédie mnohem dříve, než je o ní vyrozuměna rodina, které se daná situace týká a výjimkou není ani fakt, že právě na internetu se dotyční o události dozvědí. Př́íspěvek příbližíi prožívání zasažených osob, které si čtou na internetu př́běh a komentáře různých uživatelů na situaci, která je osobně tragicky zasáhla. Uveřejněná sdělení mohou, ale nemusí být v souladu s realitou. Hlavním zraňujícím faktorem je, že se odhalují podrobnosti z jejich soukromí, často až v intimních detailech, které se poté podílejí na sekundární viktimizaci. Následně je komplikovanější jak krizová intervence ze strany policie, tak případně další navazující terapeutická a poradenská činnost.
\end{abstract}

Klíčová slova: sociální sítě, tragické události, proživání pozůstalých, sekundární viktimizace, kazuistiky

https://doi.org/10.14712/23366486.2018.4

\section{1. Úvod}

Prezentovaný příspěvek z praxe přibližuje problematiku psychického prožívání souvisejícího se zveřejňováním citlivých informací prostřednictvím internetu po tragických událostech různého rozsahu. Vysvětluje, proč může být zveřejnění úmrtí (nejen) bezprostředně po události ve sdělovacích prostředcích devastující pro pozůstalé, rodinu a blízké. Reakci umocňuje, pokud zpráva obsahuje detaily, fotografie a bližší informace o rodině. Př́spěvek přináší poznatky o reakcích osob, kterých se tragédie dotýká a upozorňuje na další psychologické souvislosti se sdělováním informací, které jsou považovány za důvěrné, včetně diferenciace mezi tragickou událostí a násilnou trestnou činností jak z hlediska proživání, tak longitudinality. Možné typy reakcí zasažených jsou prezentovány vzhledem k rozdílným okolnostem, způsobu zjištění a fázím zpracování. Ačkoli se mohou jevit jako 
velmi podobné, vždy jsou vzhledem $\mathrm{k}$ jedinečnosti dané situace ryze individuální a ne vždy plně předvídatelné.

\section{Cíl prríspěvku}

Cílem příspěvku jsou deskripce příkladů reakcí na zjištěnou traumatizující událost a identifikace klíčových faktorů v procesu sekundární viktimizace pozůstalých a zasažených v souvislosti s uveřejňováním detailních informací o tragických událostech a trestných činech včetně fotografií na internetu a dalších médiích. Dále poukázat na odlišnosti vnímání sdělovaných zpráv prostřednictvím internetu, pokud jsme nezúčastněnými konzumenty tragických informací, anebo osobami, které při popisované tragédii přišly o osoby blízké. Definovat možné reakce na zveřejnění tragické události a motivovat k odpovědnějšímu zvažování psaní různých komentářů a vyjádření k tragickým událostem nejen ze strany laické veřejnosti ale i žurnalisti̊ a poukázat na vybrané fenomény medializace tragédií v širším kontextu.

\section{Východiska}

Na začátek chci uvést hlavní důvod vzniku tohoto článku. Osmnáct let pracuji jako policejní psycholožka a posledních osm let se intenzivně, mimo jiné, zabývám prací v rámci krizové intervence s obět'mi trestné činnosti a rodinami, které z různých důvodů při tragédiích přišly o své blízké. Velmi mě mrzí, když nastane situace, kdy se rodina o úmrtí svého blízkého dozví prostřednictvím sociálních sítí, zpravodajství, či jiných zpráv, které obletí internet. Neděje se to naštěstí vždy, ale není málo př́ípadů, kdy policie nestihne vyrozumět o smrti rodinu osobně, protože ji zprávy z internetu předběhnou. Někdy se při vyrozumívání o tragické události tzv. mineme o několik minut a přihlížíme, jak rodina hledá informace, které o ní byly napsány a tyto nemusí být zcela založeny na pravdě. Klíčovým problémem však není př́ípadné zkreslení těchto informací, ale způsob jejich podání a zjištění. Již vzniklé tragické následky bohužel zvrátit nemůžeme, ale můžeme se ze strany policie pokusit o citlivý a osobní př́istup k rodině tragédií zasažené. A zároveň osvětou apelovat na odborníky v oblasti médií i širší veřejnosti, aby si při zveřejňování reportáží a komentářů uvědomovali možný dopad na pozůstalé a chovali se v tomto ohledu odpovědněji. Ráda bych proto poukázala na to, co se může odehrát v podobě psychických reakcí a jaké komplikace může medializace neštěstí rodině přinášet.

Žijeme ve světě moderních technologií, chodíme po ulici s chytrými mobilními telefony a v dnešní době není pro nikoho problém cokoli zdokumentovat, vyfotit, natočit a ihned postoupit ostatním přes sociální sítě. Je všeobecně známo, že sdílení důvěrných informací s velkým množstvím ,přátel“ na sociálních sítích může vést k bezpečnostnímu riziku v mnoha ohledech. To, co umístíme na sociální sítě o svojí osobě, však můžeme mít relativně pod kontrolou. Díky osvětě se můžeme vyvarovat posílání např. intimních fotografií, sdělování zkušeností, se kterými se chceme svěřit pouze blízkým a opravdovým přátelům. To, že máme pocit, že tato data můžeme kontrolovat, neznamená, že se to opravdu děje. A ne vždy dotyčný anticipuje, že i jím 
uveřejněné informace mohou být ve zranitelnou dobu zveřejněny ostatním. V případě, že jsou citlivé informace zveřejněny, může být člověk naštvaný především sám na sebe, že sdělil něco, co může být zneužito.

Jinou rovinu představuje uveřejnění citlivých detailů na internetu jinými osobami (a nemusí to být pouze média), v situacích stresově vypjatých v souvislosti s tragickým úmrtím, dopravní nehodou, mimořádnou událostí, kde člověk je pozůstalým po zemřelé osobě, anebo při trestné činnosti jako obět' či poškozený. Rozdílné je uveřejnění ze strany reportérů a novinářů a uveřejnění laickou veřejností ve smyslu senzacechtivosti, sledovanosti či sdílení s co největším počtem uživatelů. Profesionální žurnalisté by měli dodržovat etický kodex a za prŕípadná pochybení ve smyslu dezinformace a hrubého zkreslení či protiprávního uvedení osobních údajů mohou být sankcionováni. Zdroj Wikipedia uvádí: „V novinářské etice se spolu střetává svoboda slova (zaručená v ČR článkem 17 Listiny základnich lidských práv a svobod, v USA Prvním dodatkem Ústavy) s obecnou mírou vkusu, ochranou soukromí, ochranou práva na čest a di̊stojnost a zodpovédným hledáním objektivní pravdy. "Příspěvky laické veřejnosti, pokud přímo neporušují zákon, bývají přecházeny a zpravidla se nikdo nepozastavuje nad jejich obsahem, který může u dotčené rodiny přispět $\mathrm{k}$ prohloubení traumatu.

Je pravda, že člověk je denně vystaven informacím o tragických zprávách ve všech médiích, právě díky rychlosti šíření zpráv všeho druhu. Jsme konfrontováni s desítkami dopravních nehod, požáry, teroristickými útoky, haváriemi, živelnými pohromami a v neposlední řadě i nešt’astnými událostmi, úrazy a násilnou trestnou činností. Přesycenost takovými zprávami často způsobuje jejich nepřesné vnímání, zkratkovité závěry, útržkovité vybavení si detailů nebo naprostou ignorací sdělovaného, kdy dotyčný zprávy sleduje, ale vlastně vůbec nezaznamená sdělované. A nutno podotknout, že toto nastává v př́ipadě, že se jej to osobně netýká.

\section{Zveřejnění tragické události v médiích}

Představte si následující situaci: Sledujete aktuální zprávy na internetu, pročítáte články a najednou uvidíte fotku zdevastovaného osobního automobilu. Jak budete takovou zprávu vnímat?

Samozrejmě záleží na spoustě dalších okolností. Reakce se bude lišit pokud:

a) Víte, že všichni vaši rodinní př́slušníci jsou bezpečně doma, nikdo z vašich známých a blízkých nevlastní podobný typ automobilu jaký je vyobrazen na fotografii a nejel do lokality, kde k tragické dopravní nehodě došlo. V tuto chvíli si můžete říci, že je to hrozné, že se zase někdo nevrátí domů a s největší pravděpodobností se začtete do dalších článků a zpráv na internetu.

b) Auto na obrázku je vám povědomé, někdo z vašich rodinných příslušníků bude mimo domov poblíž lokality, kde k tragédii došlo. Možné obavy a strach umocňuje i fakt, že se vám váš blízký neozval, nezvedá telefon, nereaguje na sms zprávy nebo je nedostupný. Zde začnou pracovat psychologické aspekty nejistoty, snaha najít co nejpodrobnější informace, detaily, porovnání dostupných zjištění z místa.

Ti, co umist'ují na internet informace z místa události, chtějí rychle druhým zprostředkovat, čeho byli svědky. Novináři chtějí co nejaktuálněji odvysílat svoji reportáž, náhodní kolemjdoucí to, co viděli na vlastní oči, někteří zdokumentovat svoji záchranářskou práci 
apod. V tu chvíli neanticipují, jaké psychické reakce vzbuzují snímky a popisy z tragické události u osob, jichž se daná situace bezprostředně dotýká.

\section{1. Varianty zjištění a reakce zasažených}

Ocitne-li se zpráva o tragické události na internetu či jinde v médiích, může se odehrát následující:

- Rodina netuší, že se něco s rodinným příslušníkem stalo a náhodně zaznamená na síti tragickou událost - objeví se zneklidnění, volání blízkým. Pokud se nedovolají a zpětně neozvou, umocní se obavy o dotyčného a vznikne akutní stresová reakce, při které se rodina snaží zjistit co nejvíce dalších informací.

- Zasažení se v přímém přenosu dozvědí o tragédii a na základě poznaných znaků (typu vozidla, individuálních detailů apod.) si jsou téměř jisti, že se jedná o jejich blízkého - což se snaží v rámci obranných mechanismů popřít, ale zároveň iniciují vlastní pátrání včetně volání na tísňovou linku nebo se vydají př́imo na místo události. V tomto případě mohou být traumatizováni sledováním scény tragédie.

- Na článek či fotografie je upozorní nějaký známý, vzbudí nejistotu a úzkost a poté následuje hodně podobný scénáŕ jako v předchozích případech.

- Rodina stále nic netuší, zprávu o tragédii nezaznamenala a absence rodinného př́islušníka nevzbuzuje obavy. To proto, že v době tragédie měl být rodinný příslušník v práci nebo na jiném místě, anebo jsou zvyklí, že se často zpozdí. Vyloučit se nedá ani možnost, že rodinní příslušníci nežijí pohromadě a vídají se pouze občas nebo jsou vztahy v rodině narušené a členové př́liš nekomunikují či se léta neviděli. Výjimkou nebývá ani to, že se tragédie stane krátce po rozloučení se po odjezdu do zaměstnání, takže se návrat dotyčného čeká až za delší dobu nebo následující den. Za těchto okolností se prodlužuje doba mezi okamžikem, kdy se událost stala a okamžikem oznámení pozůstalým a zasaženým osobám. Zde by se mohlo zdát, že je to pro rodinu nejpř́iznivější varianta, protože nežije v úzkostech z nejistoty, zda se opravdu jedná o jejich blízkého. Opak však může být pravdou. Po vyrozumění ze strany policie jsou zaskočeni, v šoku a př́padně mohou zažívat vztek či lítost, pokud zpětně vyhledají zprávy na internetu s časovými údaji o jejím zveřejnění. Může je trápit, že ostatní věděli mnohem dříve, co se stalo.

- Rodina našla informace o tragédii $v$ médiích, ale ve zprávě mohou být natolik zkreslené informace, např. o věku zemřelého, že se stále uklidňuje tím, že se nemůže jednat o jejich blízkého, ale zároveň narůstá strach a nejistota.

Vyjmenované body zcela určitě nevyčerpávají všechny možnosti, ale odráží pravděpodobný průběh jednání u osob, kterých se dotýká tragická událost.

Společnými znaky při ne zcela jasných informacích a nejistotě bývá následující:

a) Fantazie - člověk hledá vysvětlení, která jsou v souladu s jeho očekáváními.

b) Poprení toho, že se mohla tragédie stát, hledaná vysvětlení jsou komparována s těmi, která potvrzují teorii o vzniklé situaci.

c) Objevují se tzv. katastrofické scénáře, které poukazují na to, co nejhoršího by se mohlo stát. Svoji roli sehrává i minulá zkušenost, kdy se dotyčnému může vybavit situace z dříve prožitých okamžiků.

d) Znovuproživání traumatizujících vzpomínek, pokud nějakou ztrátu blízké osoby již v minulosti dotyční prožili. V takové chvíli se umocňuje senzitivita k detailům z události. V případě fotografie havarovaného vozidla to může být jeho barva a typ, 
charakteristické znaky jako např. řetízek za zrcátkem na předním skle, typické potahy, promáčknuté dveře apod.

e) Prožíání nejistoty, úzkost, panika, strach, akutni stres.

f) Aktivují se obranné mechanismy a somatické reakce na stres. Nejfrekventovanějším obranným mechanismem je racionalizace, která dočasně poskytne ryze subjektivní uspokojující vysvětlení pro jedince ohrožující situace (Vodáčková, 2004). Dotyčný začíná pátrat po dalších faktech, okolnostech a v důsledku tohoto dochází $\mathrm{k}$ aktivizaci emočních reakcí.

Průběh těchto reakcí závisí mimo jiné na míře vyhodnoceného ohrožení, na osobnostních dispozicích včetně odolnosti vi̊či zátěži a adaptačních mechanismech, v neposlední řadě na míře sociální podpory ve smyslu možnosti svěřit se se svými obavami další osobě a nezůstat na řešení náročné situace o samotě.

\section{Zkušenosti z policejní praxe}

Umístit na síti jakékoli informace je dynamičtější proces než oficiální postup vyrozumívání o tragické události a jejich následcích ze strany policie, kdy je pozůstalým a zasaženým osobám sdělena či definitivně potvrzena vzniklá skutečnost - nap̌r. smrt, zranění, úraz apod. Mezi zveřejněním v médiích a oficiálním vyrozuměním vznikne určitý časový meziprostor, ve kterém se zintenzivňují prožívané doprovodné reakce na daná zjišstění.

\subsection{Chování po sdělení tragické zprávy - tzv. vyrozumění ze strany policie}

Policisté se setkávají ve své policejní praxi s různými typy reakcí na oznámení tragické zprávy. Zpočátku je to šok, popření informace, hledání důkazů o tom, že to tak není (vždyt' jsem s otcem před chvílí mluvil, včera u mě byl, on je dobrý řidič, vždyt' jel jen na nákup apod.), bagatelizování, snaha o žert, zkoumání pravosti průkazů př́íslušníků policie, smích, fyzický kolaps, pláč, obavy z jiného důvodu př́tomnosti policie a mnoho dalších reakcí. V některých prípadech suverenita rodinných příslušníkủ, že se určitě nejedná o jejich blízkého, může znejistit policistu tak, že dokonce začne pochybovat, zda je u správné rodiny. To jsou př́ípady, kdy se např. neshoduje policistou předpokládané datum narození nebo jde o velmi krátký časový úsek, kdy se rodina se svým blízkým viděla naposledy apod. Vyrozumívání ze strany policie má své náležitosti včetně snahy o velmi citlivý a empatický př́stup $\mathrm{k}$ pozůstalým či zasaženým. $\mathrm{K}$ vyrozumění může být povolán krizový intervent policie, což je policista speciálně vyškolený k poskytování primární psychické podpory při tragických událostech. Krizový intervent nemá za úkol v takových situacích vyšetřovat, ohledávat místo činu nebo pátrat po dalších stopách apod., ale věnovat se po lidské stránce lidem, které tragédie zasáhla a být jim na blízku v těchto nejtěžších chvílích. Je tím, který naslouchá, vysvětluje postup policie, předává podstatné informace, sdílí s rodinou jejich smutek, př́padně jim zprostředkuje další následnou péči bud' ze strany policejního psychologa nebo v civilní sfére.

\subsubsection{Individuálnost prožívání tragické události}

Tragickou událost vnímá každý z nás subjektivně. Situace, kdy dojde k úmrtí blízkého člověka at' už bez cizího zavinění (nehoda, havárie, sebevražda) nebo v důsledku trestné 
činnosti, je mimořádná. Ti, kterých se týká, se na ni nemohou nijak připravit. Situace se liší jak svojí neobvyklostí, náhlostí, rozsahem, tak následky. Nelze říci, že veškeré reakce na tyto události mají ve svých důsledcích povahu psychického traumatu nebo prrímo posttraumatické stresové poruchy. Nesmíme je však podceňovat.

Kritéria pro diagnostiku posttraumatické stresové poruchy (dále PTSD) lze najít v manuálu MKN-10, tedy v Mezinárodní klasifikaci nemocí - dle aktuální platné revize). Jejími typickými př́znaky je intruze - vtíravé, neodbytné znovuprožívání tragické události včetně živých vzpomínek, snů, obrazů. Zároveň dominuje snaha popř́ít situaci a vyhýbat se situacím podobným, lidem, místům, chování, činům, které tragédii připomínají. Často prožívanými příznaky jsou pocity bezmoci, anhedonie, lhostejnost, oploštěnost emocí, podrážděnost, snížená schopnost koncentrace, absence pozitivních emocí a zvýšená psychická a tělesná vzrušivost. Traumatická reakce se může objevit být nejen u osob, které přežily setkání s násilnou trestnou činností - loupeží, pokusem vraždy, znásilněním, útokem, braním rukojmí, vážnými dopravními nehodami, setkáním se zraněním, úmrtím nebo pohledem na mrtvá těla apod., ale i u osob, které se o těchto událostech dozvěděly jako osoby blízké či rodinní příslušníci. Hluboce narušit vztahy s nejbližšími může i výrazná změna v chování nejvíce tragédií zasaženého jedince. Trauma může zasáhnout následující oblasti, potřeby (Praško, 2003):

a) blízkosti a intimity

b) otevřenosti a komunikace

c) jistoty, předvídatelnosti a bezpečí

d) pohody, radosti a uvolnění

Výjimečné nemusejí být ani př́iznaky vázané na akutní stres, poruchy přizpůsobení, přetrvávající změna osobnosti po katastrofické zkušenosti a jiná nespecifikovaná reakce na závažný stres - což jsou další diagnózy dle MKN-10, které se váží na traumatickou událost. Př́ícinou vzniklých problémů u jedince nemusí být samo trauma, ale vzniklá situace může aktivovat potíže, které byly dosud kompenzovány. Společným znakem vnímání traumatické události je narušení vnitřní kontroly nad situací, ztráta pocitu bezpečí, nemožnost uniknout následkům situace, nepochopitelnost toho, co se stalo. Událost narušuje představu světa jako předvídatelného, smysluplného a hodnotného.

Chování po traumatické události není totožné s tím, jak člověk reaguje na běžnou formu stresu. Naopak zpravidla platí, že jedná jinak. Reakce jsou často intenzivnější, hůře ovlivnitelné vưlí. V praxi to může znamenat např., že právník, který má právní vědomí na vynikající úrovni v situaci, která se jej osobně dotýká, si není ve stresu schopen vybavit žádný právní postup nebo paragraf trestného činu. Kohoutek uvádí, že: „Povaha dopadi̊ a následkủ události je dost individuální, stresová reakce však probíhá v různé míre a podobě u všech zúčastněných - u poškozených, př́slušníků širší komunity, pomáhajících či svědkư (Kohoutek, 2009, s. 30). Což nám vysvětluje, proč tragické události zasáhnou tak citelně celou rodinu, ale vlastně každého individuálně.

\subsubsection{Rozdílnost traumatizujících dopadů v závislosti na typu tragédie}

Je třeba uvést, pro lepší ilustraci, že tragické události lze rozdělit na ty, kde dojde k úmrtí:

a) vlivem nešt’astné náhody, dopravní nehody, pracovního úrazu, nedbalosti apod.

b) tragédie spojené s trestnou činností pachatele

c) sebevraždy 
Ve všech případech se dá předpokládat, že bude probíhat vyšetřování případu a průběžně uveřejňované informace se budou postupem času měnit a upravovat. Rozdílnost nastává v oblasti přisuzování viny.

U událostí v bodu a) záleží na okolnostech události, do jaké míry sehrálo zavinění např. právě u osoby zemřelého. Nicméně v prvních fázích zjištění události rodina vůbec zpravidla neprripouští případnou vinu člena rodiny a hledá zavinění u dalších, cizích osob, zaměstnavatele, jiného řidiče, přírodních vlivů či shody náhod apod.

U trestné činnosti b) by se mohlo zdát, že bude pravděpodobně vina směřována $\mathrm{k}$ pachateli a rodina bude doufat $\mathrm{v}$ jeho potrestání a v to, že následnou úlevu a zpracování tragédie přinese právě prokázání viny a jeho odsouzení. Není ale výjimkou, že se tato úleva nedostaví a smutek, lítost, zlost a další emocionální reakce nevymizí tak snadno, jak původně rodina doufala. Nehledě na to, že se takový skutek může vyšetřovat a soudit několik let. U př́padů sebevražd absentuje přesun viny na externí osobu mimo rodinu, viz níže v textu.

V průběhu času vyšetřování se v médiích mohou objevovat další doplňující informace $\mathrm{k}$ tragédiím, které mohou přinést diametrálně odlišná fakta a doplňovat již informace zveřejněné. Neznamená to však analogicky, že tím emocionálně odlehčí rodinou prožívané trauma. $\mathrm{V}$ případě trestné činnosti hraje roli proces viktimizace, což je složitý a dynamický děj, z psychologického hlediska těžko uchopitelný, protože je ovlivněn mnoha navzájem provázanými faktory (Špatenková, 2017). Obět' není poškozována pouze samotnými útoky, ale také reakcemi okolí a procesem vyšetřování, pokud je veden netaktně. Ohledně procesu viktimizace existuje řada studií a odborné literatury (např. autorek Čírtkové, Vodáčkové, Špatenkové). Pro účely tohoto příspěvku dominuje vliv sekundární viktimizace.

Sekundární viktimizací se nazývá druhotná újma od sociálního okolí, respektive, jak na událost reaguje nejbližší okolí nebo různé instituce (policie, soud...) (Čírtková, 2000). Sekundárně viktimizovat mohou orgány činné v trestním řízení, obhájce pachatele, svědek, znalec, okolí oběti a v neposlední řadě i média. Sekundární viktimizaci definuje také zákon o obětech trestné činnosti, který ji vymezuje jako: ,újmu, která nebyla oběti způsobena trestným činem, ale vznikla v důsledku přistupu Policie $\check{C} R$, orgánů činných $v$ trestním ř́zení a dalšich orgánů veřejné moci, poskytovatelů zdravotních služeb, subjekti̊ zapsaných v registru poskytovatelì pomoci obětem trestných činü, znalců, tlumočníkì, obhájců a sdělovacích prostředků k ni'“ (§2 odst. 5 zákona č. 45/2013 Sb, o obětech trestných činů a o změně některých zákonů).

Nejenom v procesu viktimizace se objevují tzv. druhotné rány psychického rázu. Podobným způsobem dochází ke zpracování jiných traumatizujících událostí - např. dopravní nehody, mimořádné tragédie, neštěstí. Vysvětlením je to, že jsou to události silně stresující, neočekávané, nepředvídatelné, není možné se na ně předem připravit, vlastním přičiněním se jim vyhnout a hlavně se s nimi rozumově vypořádat. Jsou prožívané jako krize a narušují vnímání sebe sama (Čírtková, 2013).

Po oznámení spáchání trestného činu rodina nejčastěji hledá vinu u pachatele, u oběti to není ale tak jednoduché. Obět' zpravidla chce sama pro sebe pochopit, proč zrovna ona se stala obětí trestného činu. „Ve své mysli se opakovaně vrací k události, hledá svoje osobní vysvětlení v mentálních pochodech, které nazýváme ,překontextování či přeznačkováni události . Tento proces hledání smyslu je dỉležitý pro obnovu iluze kontroly. Je běžné, že obět'v pochodech překontextování připisuje vinu za spáchaný trestný čin sama 
sobě (nemèla nikam chodit, otevírat dveře, měla tušit nebezpeči apod.). Sebeobviňování (přijetí myšlenky o domnělé vlastní spoluvině) představuje často jediný volný a současně věrohodný prvek, který může obět použit pro pochopeni toho, co se stalo. Ač to zni paradoxně, působi sebeobviňováni (alespoň některé jeho formy) ozdravně, protože redukuje nevysvětlitelnost a iracionalitu trestného činu z pohledu oběti. Sebeobviňování je vnitřní psychický mechanismus, souvisejicí s postupným zpracováváním kriminálního činu v mysli obětic“ (Č́rtková, 2013, s. 134-135).

Považujeme za důležité uvést, že je mylné domnívat se, že obět' trestného činu touží po pomstě či odplatě. Její hlavní potřebou nemusí být ani pomsta, ani potrestání pachatele, ale obnova pocitu vlastního bezpečí a pochopení individuálního významu a smyslu kritické události.

Vzhledem k tomu, že soudní procesy mají určitý časový průběh, může se stát, že reportáže o konkrétním trestném činu se během nějaké doby opakují, připomínají se a shrnují klíčové informace, sled událostí, doplňují se snímky a poznatky z vyšetřování. Někdy dojde ke spáchání podobné trestné činnosti a potom je v souhrnu uvedeno vícero vyšetřovaných kauz. To znamená, že pozůstalí stále mohou ve zprávách vidět opakování reportáže či její části včetně doprovodných fotografí. Tímto dochází k oživování detailů a možné re-traumatizaci při znovuprožívání oživených stresujících okamžiků.

Bod c) specifickým př́kladem mohou být zveřejňované př́pady sebevražd, které rodinu velmi citlivě zasáhnou a také si dovolím, ze své praxe tvrdit, že krizová intervence a psychologická péče o pozůstalou rodinu je $\mathrm{v}$ těchto př́ípadech ještě mnohem náročnější. Členové rodiny mohou prožívat hlubší pocity viny uvnitř sebe, obviňují se, že mohli tragédii zabránit, měli se více zajímat o svého blízkého, rozmluvit mu jeho úmysly, hlídat jej apod. Na tomto místě je naprosto zásadní zmínit, že dospělý člověk nese plnou odpovědnost sám za své rozhodnutí ukončit život a řešit suicidálním chováním své problémy. Nicméně pokud si rodina přečte $\mathrm{v}$ médiích spekulace o důvodech suicidia a detailní intimní informace o svém životě, i zde medializace přispívá k traumatizaci. Zraňující mohou být komentáře, které spekulují o důvodech sebevraždy, haní rodinu, že dotyčnému v činu nezabránila, mohou odsuzovat př́stup rodiny a její zvyky, očerňovat její členy apod. Zpravidla se za sebevraždou neskrývá jen jeden důvod a v některých př́padech (pokud např. neexistuje dopis na rozloučenou) se přesné pohnutky zemřelého rodina nikdy nedozví. I toto může přispívat $\mathrm{k}$ negativním faktorům zpracování tragické události. Lidé $\mathrm{v}$ dnešní době hodně sledují názory na facebooku a dalších sociálních sítích, diskuse, vyjádření a není výjimkou, kdy ještě před krizovým interventem policie rodina hledá informace $\mathrm{k}$ tragédii na internetu. Občas je dopis na rozloučenou zveřejněn i na facebookovém profilu. Zde může vyvstat otázka na zamyšlenou: Jak tato, v mnoha př́ípadech, vysoce emotivní sdělení působí nejen na pozůstalé, ale i na uživatele a čtenáře textu?

Dalším motivem hledání zprávy na sociálních sítích je zjistit reakci kamarádů, přátel a blízkého okolí. Pozůstalí si chtějí tyto reakce přečíst a zároveň je jejich čtení zraňuje. $\mathrm{V}$ praxi se můžeme setkávat $\mathrm{s}$ tím, že sebevraždě předcházely narážky zemřelého „na konec“, který nebyl specifikován a rodinu vůbec nenapadlo zeptat se či pátrat, nebo nevěřili, že by jejich blízký chtěl spáchat sebevraždu. V některých př́ípadech sehrály roli zažité mýty o sebevraždách a podcenění situace. Jindy byla rodina již unavená předešlými avízy o ukončení života, ale nebrala je vážně. 


\section{Kazuistiky}

V následujícím textu si představíme několik kazuistik, které doplníme analýzou možných traumatizujících dopadů, doprovodných reakcí a konkrétních faktorů, které se mohly podílet na sekundární viktimizaci.

\subsection{Dopravní nehoda}

Po jedné tragické dopravní nehodě, kde zemřela mladá žena, se na sociální síti objevily komentáře $\mathrm{k}$ jejímu manželskému svazku s tím, že se pár měl rozvádět.

Autoři příspěvků spekulovali o tom, nakolik manžel zemřelé mohl za řidiččin psychický stav, který mohl přispět ke vzniku nehody. Komentáře šly ještě více do „hloubky“ ohledně materiálního zajištění nynějšího vdovce, toho, že nyní dosáhl svého a zdědí celý rodinný majetek. Uveřejněné texty prohloubily vdovcovu emocionální reakci na již tak hrozivou ránu v podobě ztráty manželky, matky svých dětí. Tento muž přiznal při krizové intervenci výčitky ohledně předcházejícího způsobu komunikace se svojí ženou.

Pocity viny zpravidla doprovázejí reakci na jakoukoli tragickou zprávu, kdy člověk rekapituluje, zda nemohl jiným způsobem chování odvrátit určitou událost nebo podíl na ní. Reakce veřejnosti $\mathrm{v}$ tomto prŕpadě pocity viny prohloubily a zintenzivnily $\mathrm{i}$ jeho emocionální reakci a stud před svým okolím. I zde zafungoval iracionální, ale mezi lidmi zakořeněný mýtus, že co se objeví v médiích, musí být nutně pravda. Mnoho lidí jedná pod vlivem sociálního tlaku s tím, že se chce zavděčit co nejvíce osobám a žít v souladu $\mathrm{s}$ jejich očekáváními. Chtějí vypadat $\mathrm{v}$ jejich očích co nejvíce sociálně žádoucím způsobem, což v kontextu uveřejněných detailních informací komplikuje návrat $\mathrm{k}$ běžnému sociálnímu kontaktu. Proto i zde uveřejněné detaily komplikovaly návrat manžela zemřelé zpět do každodenního života jak v pracovním, tak osobním životě. Musel se potýkat s nepř́ijemnými pocity, jak ho bude okolí vnímat na základě „uveřejněné pravdy“.

\subsection{Neštěstí v dopravě}

Další př́běh z praxe: Po jedné neštastné události v dopravě, při které došlo $\mathrm{k}$ úmrtí malého dítěte, obsahovaly komentáré na internetu nadávky směrem $\mathrm{k}$ rodičům, volání po důsledném potrestání těchto rodičů, kteří jsou „nemožní, nezodpovědní, neměli mít vůbec děti“" apod. Jak se mohli tito rodiče cítit? Ve své podstatě bylo těmito očerňujícími komentáŕi narušeno vlastní pojetí sebe jako tzv. „dobrého rodičc“, byli dehonestováni a pranýřováni a byla jim implantována vina. Tyto reakce mohly zapř́činit vznik posttraumatické stresové reakce, protože se zde kombinují již tak spontánně vzniklé pocity viny, reakce na událost, znovuproživání tragického okamžiku, vnitřní napětí, vztek, lítost, strnulost, otupělost a snaha o sociální únik. Nutno říci, že zde zraňující komentáře vznikly bez jakékoli znalosti bližších okolností a detailů. Většina tragických událostí, kde dochází $\mathrm{k}$ vyšetřování př́íčin, bývá medializována $\mathrm{v}$ určitých časových intervalech. Poprvé bezprostředně po události, poté při zjištění nových skutečností, dále připomínána v souvislosti $\mathrm{s}$ podobnými neštěstími a také $\mathrm{v}$ průběhu soudního procesu. $\mathrm{V}$ tomto prípadě soud shledal rodiče jednoznačně nevinnými v souvislosti se zaviněním smrti jejich dítěte. Nicméně již zveřejněné komentáře, $\mathrm{v}$ podobě soudů založených na domněnkách $\mathrm{v}$ počátku př́ípadu a průběhu jeho vyšetřování, byly výrazným stresovým faktorem, který zasáhl celou rodinu. Zveřejňování informací po delší časový úsek se podílelo na její neustálé retraumatizaci a izolování od sociálního okolí. Bohužel ne vždy tzv. „dobrý konec“ funguje v podobě 
ospravedlnění a očekávané úlevy, protože podstata tragédie, tedy ztráta vlastního dítěte, je nezvratitelná skutečnost a pro rodiče největší možná ztráta.

\subsection{Případ několikanásobné vraždy}

Následující případ popisuje traumatizaci rodiny po několikanásobné vraždě, jejíž způsob provedení otř́s i zkušenými kriminalisty a dalšími policejními odborníky. Pro novináře to byla zpráva číslo jedna a zaplavovala titulky deníků i diskusní portály. Novináři doslova mapovali minutu po minutě zasažené členy širší rodiny, začali spekulovat např. o ochotě pozůstalých zorganizovat poslední rozloučení, což z hlediska míry traumatizace bylo pro rodinu doslova devastující. Zároveň v reportážích hovořili o způsobu trávení volného času rodiny a hodnotili, jak je možné, že rodina tráví čas na zahradě a pije kávu. Jakou činnost asi měla rodina vykonávat, aby naplnila představy novinářư?

Pro pozůstalé je jedním z efektivních způsobů zpracování traumatického zážitku dodržování pravidelného režimu a běžných zvyklostí, které jim dodávají potřebnou míru předvídatelnosti, jistoty a bezpečí. Pití kávy na zahradě pospolu ukazuje na soudržnost a sociální podporu jako podpůrné mechanismy zvládání traumatu.

\subsection{Na první pohled vražda}

Další kazuistikou je událost, která na začátku vyšetřování vypadala jako vražda. Došlo k úmrtí mladé ženy, zranění potenciálního pachatele, který skončil v cele předběžného zadržení. Žena zemřela při poskytování první pomoci svými rodinnými příslušníky. O celé události se ihned psalo. Vypadalo to, že je jasný viník, pachatel, kterého místní obyvatelé okamžitě odsoudili. Postupným vyšetřováním se zjistilo, že se sice pár popral, ale smrt nebyla zapříčiněna cizí vinou, nýbrž zdravotními komplikacemi, které propukly v průběhu incidentu. Také pro rodinné prŕíslušníky byl naprosto klíčový fakt, že neposkytli špatně první pomoc a v žádném případě nemohli úmrtí zabránit. Potenciální pachatel byl propuštěn, vlastně se vůbec ničeho nedopustil, protože potyčku vyvolala zemřelá a naopak mylně označený pachatel byl najednou obětí, která byla sama vážně zraněna.

Muž si v prvotní fázi na internetu o sobě přečetl, že je pachatelem vraždy a bylo pro něho nemyslitelné zůstat v původním místě bydliště. Obával se reakcí okolí, pomluv a jeho touha přestěhovat se byla způsobena potřebou odpoutat se od minulosti, izolovat se od dosavadního způsobu života a začít život na místě, kde o něm nikdo žádné informace nemá.

V podobných případech je nezbytné, aby byly zveřejněny i vysvětlující informace, dementováno to, co bylo původně napsáno, a poškozené osoby byly ospravedlněny a předešlo se vzniku psychických problémů, které jedince inhibují v běžném způsobu života. Zpravidla se toto neděje nebo s velkým časovým odstupem, kdy již není možné odstranit vytvořené všeobecné mínění. Sami jedinci se pak nejsou schopni, vzhledem k prožívanému, obhájit. Nedokáží sami vysvětlit, jak se událost stala. Obávají se, že jim nikdo nevěří a opravdu tomu kolikrát tak je. Často rezignují a postrádají sílu k dalšímu sebeobhajování pod tíhou psychického i fyzického vyčerpání.

\subsection{Smrtící tragédie on-line}

Při psaní tohoto článku nelze nezmínit i četně medializovaný př́íspěvek, který obletěl internet. Konkrétně zveřejňující smrtící video online. Video zachytilo rychlou jízdu dvou mladých žen $\mathrm{v}$ prrímém přenosu, včetně komunikace s dalšími přáteli a končící nárazem auta do protihlukové stěny. Spousta lidí si pustí medializované video ze zvědavosti, 
senzacechtivosti. Hojně diskutované je použití získaného materiálu k preventivním účelům, ale co rodina aktérek? I samotné úvahy z hlediska právního, odkazy na ochranu osobních údajů a celkově probírání této aktuality v různých médiích mají zraňující dopad na rodinu obou dívek. Samotné video nese velmi citlivé údaje, byt' obličeje obou žen byly rozostřeny. Video vyvolalo bouřlivé emoce a je to zcela logické.

Přeživší ženu může jeho shlédnutí retraumatizovat, vyvolat silné doprovodné emoce a vzpomínky na zlomový okamžik v jejím životě, což může mít vliv i na př́padnou rekonvalescenci a zotavování nejen po psychické stránce. Zároveň rodinu zemřelé dívky zcela pravděpodobně zasáhlo zhlédnutí posledních sekund života, které mohl sledovat kdokoli. Jsou to vysoce intimní chvíle, které pro pozůstalou rodinu mají zcela jiný vypovídající rámec než prosté shrnutí do konstatování, že takto rychle se nejezdí, jakých přestupků se dívky dopustily apod. I pro jedince s vyšší vulnerabilitou, který je vtažen do kontextu jízdy zobrazené na videu, se „neznámé“ dívky stanou postavami, o kterých má nějaké informace, tedy nejsou to úplně anonymní osoby, a o to silnější dopad může mít právě shlédnuté video na diváka. Vůbec se nemůžeme divit, že rodiny dívek volaly po odstranění videa ze sociálních sítí, nechtějí si znovu a znovu připomínat kruté okamžiky této události. Není to film, není to inscenace, je to odraz reálného kontaktu se smrtí, který má na psychiku zasažených osob - myšleno i širší rodiny a přátel dívek, velký vliv. Někdy uživatel internetu ani nemá v úmyslu hledat tragické zprávy nebo videa. Jednoduše se může stát, že na internetu narazí na odkaz „zajímavé video“ a po kliknutí se mu spustí právě záznam události pro něho tak tragické.

\section{Společné rysy reakcí navzdory jedinečnosti situací}

Mnohé projevy jsou u pozůstalých či jinak zasažených osob po tragédiích velmi podobné. V následném období (a je to i doba, kdy se mohou dále uveřejňovat další fakta) dochází ke snížení koncentrace, pocitu derealizace, depersonalizace, jakoby žili ve snu či sledovali film o své osobě. Zhoršuje se interpretace informací, kolísá nálada, pocity nejistoty, roste sklon k paranoidním myšlenkám apod. (Lägerbäck, 1995).

Reakce na tragickou událost má svoji dynamiku a vývoj. Těsně po vyrozumění ze strany policie či seznámení se s tragédií na internetu se setkáváme nejprve s fází šoku. Člověk je zaskočen událostí, může ztuhnout, popírá, co se stalo, má dojem snu, nereality, nevěří sdělovanému. Někdy člověk není schopen mluvit, vyjadřovat se, neuvažuje racionálně. Fáze šoku nastupuje většinou při oznámení tragédie a trvá, opět individuálně, od několika hodin po delší časový úsek, i třeba v rozpětí několika dní. Ve fázi šoku může být navenek patrné expresivní chování - silné doprovodné emoce, křik, pláč, zvýšená gestikulace, vztek, strach, záplava slov. Nebo kontrolované chování, které je jeho opakem, kdy osoba vypadá odosobněle, jakoby se jí zpráva netýkala, chová se chladně, strnule. Laickým pohledem působí nezúčastněně, troufale řečeno slýcháme z úst policistů „vypadali v pohodě“. Toto tvrzení pramení z mylného výkladu šokové fáze, kdy osoba reaguje na dotazy okolí a působí přirozeně, př́padně chce něco organizovat. V podobě tělesných př́iznaků dochází k pocení, třesu, pocitu těžkých nohou, nucení na močení, aktivizaci, neschopnosti setrvat na místě nebo naopak k nemožnosti se pohnout. Na úrovni psychické je to otupělost, proměnlivé emoce od vzteku k zoufalství, pocitu bezmoci, neschopnost „,vypnout“. Myšlenky ovlivňují silné emoce, člověk není schopen zpracovat, co se stalo, může se snažit úplně 
popřít vzniklou situaci, což se nejčastěji projevuje mluvou o zemřelém v budoucím čase např. až přijde domů, musím mu uvařit večeři apod. Někdy lidé potřebují být v pohybu, cítí se nepř́ijemně a nevydrží v klidu, mají potřebu normalizovat situaci např. uklízet, což je vedeno i snahou přesunout pozornost jinam a vypadat „dobře“ “ i za této mimořádné situace, takže před policistou myjí nádobí, věší záclony, rovnají nákup do ledničky apod.

Konečný dopad na zveřejnění tragických událostí je sice individuální, ale zpravidla závisí na osobnostních rysech, věku, aktuálním psychickém a zdravotním stavu a dosavadních zkušenostech, včetně reakce blízkého okolí (Velikovská, 2016). Horší průběh reakce na zátěž bude u osob, které jsou úzkostnější, introvertní nebo se sklony k neuroticismu.

Celkově psychické dopady nejsou vždy predikovatelné, nebot' se liší co do intenzity, hloubky a šíře projevů následně i longitudinálně po události.

Nelze přesně procentuálně vystihnout, kolik osob bude vykazovat známky traumatu po prožití tragické události a kolik takových zvládne situaci relativně „,bezproblémově“ díky sociální podpoře. Z hlediska kriminality se žádné oficiální statistiky mapováním jejich „pouze psychických dopadư“ nezabývají. Policejní evidence započítává např. psychický šok do kategorie ,jiných následkư “ trestného činu, které postihují zhruba dvě třetiny obětí (rok 2013 - 68,2 \%, rok 2010 - 67,4 \%). Tento údaj však nemá výpovědní hodnotu, nebot' je do stejné kategorie zahrnována i majetková újma, tj. asi 70 \% všech těchto osob tvoří oběti krádeže (Velikovská, 2016, s. 105).

\section{Shrnutí dopadů medializace a potřeb zasažených}

Znovu si shrňme několik rysů společných pro tragické události. Většina tragédií je veřejností zaznamenána a láká novináře i zvědavce. Právě z tohoto důvodu se zasažení stávají loutkami spletitosti událostí. Nemohou ovlivnit, co se o události a jich samotných napíše.

Zveřejnění výše popsaných situací narušuje a komplikuje pozůstalým právě ono důležité vykonávání běžných denních povinností a návrat k pravidelnému režimu, které je mimo jiné nezbytné k překonání traumatu. Aby pozůstalí zabránili šíření dalších informací o svém chování, vyhýbají se společenskému životu, izolují se, někteří zůstávají v pracovní neschopnosti, aby zabránili kontaktu s kolegy, předešli vyptávání se. Jsou vysoce zranitelní, senzitivní na jakýkoli detail, stávají se obětí nechtěné veřejné exhibice. Ztrácejí kontrolu nad situací, nemohou ovlivnit prezentované informace, které nemusejí a zpravidla úplně nekorespondují s realitou. Už samotné palcové titulky článků akcentují zranitelnost poškozených. Na veřejnost se dostávají často informace, které dychtí po senzaci a čtivosti, ale zároveň odkrývají o pozůstalých a rodině skutečnosti, které mají zůstat v soukromí.

Pozůstalí někdy i tajně organizují pohřeb a obávají se zveřejnění místa a času konání. Někdy zveřejněné informace vedou i k rozkolu uprostřed rodiny, kdy je naopak přes média vzkazováno dalším rodinným příslušníkům, že nejsou na pohřeb zváni a je snaha jim takto zamezit poslednímu rozloučení.

Typickými reakcemi je i touha vypátrat všechny dostupné informace k tragédii a snaha je vymazat, volání po zastavení šíření a sdílení dalších zpráv o tragédii. Počáteční hledání fotografií, záznamů, všech informací a postupem času vysoká senzitivita k jakýmkoli jiným špatným zprávám nebo naopak otupělost, útěky do nemoci, izolace od okolí, zvýšená iritabilita k dotazům na událost apod. 
Zejména v takto exponovaných chvílích zasažení událostí potřebují takt, citlivý přistup a ochranu privátního života. V této, pro ně velmi vypjaté době, se ocitají na jevištní scéně s plně zapnutými reflektory v pozornosti každého, kdo si přečte o jejich osudu.

Nezbytné je si uvědomit fakt, že vlastně jakoukoli zveřejněnou informaci z našeho života, kterou napíše o nás někdo jiný, podrobujeme vyšší kritice a zabýváme se jí mnohem analytičtěji a zkoumáme, jak byla myšlena. Kdo si ničím takovým neprošel, neumí si představit, co prožívají ti, kterých se tragédie týká.

Někteří novináŕi jsou ochotni v honbě za senzacemi zneužít jakoukoli slabost ze strany obětí, pozůstalých, náhodných svědků apod. Svůj efekt má i doprovod textu fotografiemi či sestřihem obsahu události podbarveným hudbou, která podtrhuje emotivní charakter situace (Velikovská, 2016).

$\mathrm{Na}$ traumatizaci se mohou podílet nejenom novináři, ale i, jak bylo výše popsáno, nevhodné komentáře uživatelů sociálních sítí, kteří hodnotí publikovaný text. Objevit se mohou odsuzující reakce směrem k pozůstalým, které vycházejí z nepodložených informací o události. Celkově lze média považovat za jednoho z původců sekundární viktimizace, protože jednak mohou zvýšit utrpení oběti, zneužít pozice vztahu mezi obětí a reportérem a sdělení mohou vyznít ve smyslu rad oběti, co by pro ni mohlo být dobré (Kunczik, Bleh, 1995).

Výraznou potřebou při prožívání závažného stresu je včasná a přiměřená pomoc od okolí. Nemusí se jednat jen o pomoc ze strany profesionálů, pomáhá i sociální podpora okolí. Ta může rozhodujícím způsobem ovlivnit zpracování traumatického zážitku. Bohužel ne vždy musejí mít sociální interakce pozitivní dopad. Podporu může totiž potřebovat i ten, který ji sám poskytuje - tedy například rodina. S poskytováním opory souvisí i její dostupnost a užitečnost. Vědomí, že pomoc je dostupná, dosažitelná a účinná, představuje pro zasažené v souvislosti s vyrovnáváním se s důsledky traumatu velmi důležitou zprávu (Kohoutek, 2009). I to je jeden z důvodů, proč krizový intervent policie nabízí psychickou pomoc nebo se snaží zprostředkovat kontakt na pomoc následnou.

\section{Další postřehy k medializaci tragédií}

V souvislosti s médii nesmíme zapomenout zmínit i další fenomén, tzv. „vylepšování příběhu“ (Vymětal, Vitoušová a kol. 2008 s. 16), což může znamenat přidání, upravení, jiný kontext tragické situace popisované v médiích, která se ještě větší měrou bude podílet na traumatizaci obětí. Také frekvence, častost expozice fotek, videí z tragické události sehrává svoji roli v prožívání zasažených osob. Proto je pozůstalým doporučováno v rámci krizové intervence, aby nesledovali zprávy o „svojí tragédii“ v médiích, nevyjadřovali se na kameru novinářům a jsou informováni i o tom, že pokud nechtějí, nemusejí vyprávět svému okolí, co přesně se jim stalo a vysvětlovat, jak se cítí. V těchto těžkých chvílí potřebují klid, soukromí, oporu svých nejbližších, zachovat svůj pravidelný režim, pečovat sami o sebe jak psychicky (nap̌r. vyhledáním odborné pomoci), fyzicky (odpočinkem, stravou, spánkem) a čas. Jednoduše řečeno, nejvýstižněji by možná zněla tato věta, na které by se shodla většina zasažených rodin: „Už nás nechte žít, už o nás nepište, už dost“.

Za zmínku stojí další poznatek v souvislosti s medializací a to v prŕípadech tzv. fenoménu nepravých obětí. Pokud je médii prezentován podrobně se všemi detaily nějaký případ tragédie a debatují o něm odborníci a experti, může tento prríběh zaujmout jedince, 
kteří pocit'ují svůj život jako prázdný, nenaplněný, neuspokojivý ve smyslu svých plánů a cílů. Událost zmiňovaná v médiích je zaujme a hledají o ní další a další informace. „Postupně se v pochodech autostimulace dostávají do stádia, ve kterém již nerozlišují, zda jejich viktimizace spočivá na autentických osobnich záżitcích či je výsledkem mediálně zprostředkovaných procesủ imaginace a identifikace. Showalter (1997) označuje popisované mechanismy jako, hysterické epidemie v epoše médii " "(Č́rtková, 2013, s. 142). Princip popisovaného je, že u této potenciální nepravé oběti se rozběhne proces viktimizace indukované médii jako sociálně identifikační proces. Obět nejprve pojme podežrení, že by se medializovaný problém mohl týkat jí a postupně informace prezentované v médiích spojuje se svými obtížemi, dále vyhledává informace a utvrzuje se, že to, co se jí děje a postrádá to smysl, má své odůvodnění (a je to pochopitelné ve smyslu viktimizace) a rozbíhá se proces falešné viktimizace. Dochází k identifikaci s referenční skupinou a vyhledávání výhod včetně psychosociální pomoci.

\subsection{Pozitivní vliv médií}

Nesmíme zapomenout na prípady, kdy při tragických událostech média potřebujeme. A to v situacích, kdy se pátrá např. po nezletilé osobě, je třeba v souvislosti s trestnou činností varovat veřejnost před nebezpečným pachatelem nebo informovat při hromadných neštěstích další osoby, aby se předešlo ztrátám na životě a majetku. $V$ takových př́ípadech je role médií nezastupitelná a správně načasovaná a srozumitelně podaná informace může od začátku události znamenat zásadní př́nos ke zvládnutí situace. Nesmí se ani zde podcenit síla sdělovaného, je třeba pečlivě volit slova a pracovat citlivě s informacemi. Je nutné být opatrný při popisu detailů i volbě doprovodných fotografií. Oběti a zasažení zde mají právo na ochranu i v prŕípadech, kdy jim zveřejnění konkrétního př́íběhu může pomoci.

$\mathrm{Na}$ tomto místě je třeba uvést i príklady pozitivně působících komentárů. A to v situacích, kdy jsou uveřejněné zprávy o tragických událostech, jako jsou např. živelné pohromy, mimořádné události velkého rozsahu apod. Ty mohou iniciovat diskuse a komentáře široké veřejnosti na sociálních sítích, které mohou působit podpůrně, empaticky, dodávat zasaženým odvahu, že vše zvládnou a mobilizovat jejich fyzické i psychické síly. Potom mají tyto komentáře kladný efekt a ukazují sdílení, solidaritu se zasaženými, porozumění v těžké životní situaci a mohou nabízet psychickou, informační nebo instrumentální pomoc.

Nutno ještě podotknout, že i při psaní tohoto př́spěvku byly, s ohledem na citlivost informací, některé skutečnosti, byt' anonymizované, ještě upraveny, aby sama autorka neprozradila citlivé informace z jednotlivých kauz. Autorka je policejní psycholožka a koordinátorka týmu pro pomoc obětem trestné činnosti, která přichází do bezprostředního kontaktu s pozi̊stalými a zasaženými tragickými událostmi a v rámci svých možností dbá na to, aby tragické zprávy byly prostřednictvím Policie České republiky sdělovány ohleduplně, citlivě a včas a zasaženým osobám byla nabídnuta první psychická pomoc a krizová intervence.

\section{Diskuse}

V současnosti je zcela nemožné vyhýbat se negativním zprávám a celkově informacím o dění nejen v České republice. Je to přirozené, že se zajímáme o zprávy, včetně nepř́íjemných a tragických událostí. Nabízí se však otázka, proč mají lidé tak velkou potřebu 
zaměřovat se právě více na negativní zprávy, kde dojde k úmrtí, pídit se po detailech a vyhledávat senzace. Neuvědomují si, že na druhé straně jsou osoby, kterých se popisovaná událost týká, odhaluje intimní detaily z jejich života, odkrývá fakta, která měla zůstat v rodinném kruhu. Nemůžeme nikomu, v mezích zákona, zakázat vyjadřovat se na sociálních sítích. Rozhodně nikomu nepřejeme, aby si roli osob, o kterých se v kontextu tragických událostí píše, vyzkoušel sám. Nicméně větší osvětou a př́iklady, jakým způsobem a proč sdělované na sociálních sítích ovlivňuje životy lidí, kterých se týká, mưže vést k prevenci ve smyslu pečlivého zvažování k čemu a za jakým účelem se budeme vyjadřovat, co budeme komentovat nebo koho budeme kritizovat za např. laxní př́stup, zanedbání péče apod. Možná, pokud by si dotyční, kteří se takto k událostem vyjadřují, uvědomili, že popisované nemusí plně korespondovat s realitou, a že napřr. pozůstalým, díky nevhodně voleným verbálním obsahům implementují či jim posilují pocity viny a podílejí se na sekundární viktimizaci, snížil by se počet těchto ne prŕliš senzitivních komentářů a zasaženým osobám by tento fakt mohl usnadnit následné vyrovnávání se s traumatem. Jiný úhel pohledu by článek mohl přinést i reportérům informujícím o tragických událostech. Mohl by vést k zamyšlení se, zda by bylo možné a jistě i vhodné navázat spolupráci s policií ve smyslu vyčkání s uveřejněním těchto zpráv až poté, co o nich osobně bude informována rodina a předejít tak citelnému zásahu do soukromí zveřejněním toho, co musí být učiněno osobně, citlivě a s taktem. Tato opatření by vyžadovala řadu legislativních úprav, ale byly by to kroky zcela určitě správným směrem.

\section{Závěr}

Pokud se po přečtení tohoto př́íspěvku začnete dívat jinýma očima na zveřejňované informace a komentáře prostřednictvím internetu a médií, tak splnil svůj účel. Možná ted' budete sledovat zpravodajství ohledně tragických zpráv mnohem pozorněji a bedlivě zvažovat, zda a co budete sami komentovat na sociálních sítích. A to proto, že si mnohem více uvědomíte zranitelnost osob, kterých se jakékoli neuvážené komentáře bezprostředně týkají. Právě jste dočetli můj příspěvek, rozhodně nikomu nepřeji nic zlého, ale přesto si dovolím ukončit text následujícími otázkami na zamyšlení: Chtěli byste objevit citlivé informace v souvislosti s tragédií o své rodině a svých blízkých v médiích? Vidět je ještě dříve než se oficiálně o tragédii dozvíte od policie? Chtěli byste sledovat detailní fotky z místa tragédie či číst jízlivé, případně negativní nebo spekulativní komentáře?

\section{LITERATURA}

Brož F., Vodáčková, D. (2015): Krizová intervence v kazuistikách. Praha: Portál. Čech, J. (2012). Policajná psychológia I. Univerzita sv. Cyrila a Metoda v Trnave. Čech, J. (2012). Policajná psychológia II. Univerzita sv. Cyrila a Metoda v Trnave. Čech, J. (2012). Policajná psychológia III. Univerzita sv. Cyrila a Metoda v Trnave. Č́rtková, L. (2000). Policejní psychologie. Praha: Portál.

Čírtková, L. (2013). Forenzní psychologie. Plzeň: Vydavatelství a nakladatelství Aleš Čeněk, s.r.o. Hartl, P., Hartlová, H. (2000). Psychologický slovnik. Praha: Portál. 
Hodurová, D. (2012). Zdroje stresu u policistů. Diplomová práce, Masarykova Univerzita v Brně.

Jones, G., Moorhouse, A. (2010). Jak ziskat psychickou odolnost. Praha: Grada.

Kirschmanová, E. (2015). Život s policajtem, vše co by měla rodina policisty vědět. Praha: Grada.

Kohoutek, T., Čermák, I. (2009). Psychologie katastrofické události. Praha: Academia.

Krech, D., Crutchfield, R. S., Ballachey, E. L. (1968). Člověk v spoločnosti. Bratislava: Slovenská akademie věd.

Křivohlavý, J. (2001). Psychologie zdraví. Praha: Portál.

Křížová, Z. (2007). Profesni zátěž policistů a její proživání. Diplomová práce, FF Masarykova Univerzita v Brně.

Kunczik, M. (1995). Základy masové komunikace. Praha: Karolinum.

Lägerbäck, B. (1995). Oběti zločinu a jejich reakce. Praha: BKB.

Martinková, M. (2010). Co přinesly policejní statistiky v roce 2009 o obětech kriminality v ČR. In A. Marešová et al. Analýza kriminality v roce 2009 a v předchozím dvacetiletém obdobi, Praha: IKSP, S. 70-92.

Nakonečný, M. (2005). Sociální psychologie organizace. Praha: Grada.

Nakonečný, M. (2009). Sociální psychologie. Praha: Academia.

Praško, J. a kol. (2003). Stop traumatickým vzpominkám. Praha: Portál.

Powell, M. B., Tomyn, A. J. (2011). Life satisfaction amongst police officers working in the area of child abuse investigation. International Journal of Police Science nad Management. 13(2).

Rubinová, G. (2015). Zvyk není železná košile. Praha: Beta.

Spurný, J. (2005). Komunikačně náročné situace v policejni praxi. Plzeň: Vydavatelství a nakladatelství Aleš Čeněk, s.r.o.

Špatenková, N. (2004). Krize psychologický a sociologický fenomén. Praha: Grada.

Špatenková, N. a kol. (2017) Krize a krizová intervence. Praha: Grada.

Tecl, J. (2013). Motivace a postoje k profesi stráźníka obecní policie. Diplomová práce, Univerzita Tomáše Bati ve Zlíně.

Tepperwein, K. (2013). Krize jako šance. Bratislava: Noxi.

Velikovská, M. (2016). Psychologie obětí trestných činů. Praha: Grada.

Vymětal Š., Vitoušová, P. (2008). Novináŕi a oběti trestných činů. Ministerstvo vnitra ČR

Zákon o obětech trestných činů a o změně některých zákonů č. 45/2013 Sb.

Žurnalistická etika. Dostupné na: https://cs.wikipedia.org/wiki/Žurnalistická_etika

\section{THE NECESSITY OF THE PROTECTION OF THE PRIVACY OR DEVASTATING IMPACT OF THE INTERNET IN THE TRAGIC EVENTS TO THE FAMILY AND BEREAVED}

\section{VLÁŠKOVÁ}

\section{ABSTRACT}

The aim of this contribution is to convey the knowledge from the practice about the hurting impact on the psyche of the family and the bereaved of the victims of crimes, tragic events and the extraordinary disasters in case the information about the event is published on the social networks and news portals on the Internet. It is not the aim of this paper to name all the reactions and possibilities. It aims to present a different point of view on the publishing of this kind of information and makes the readers to think about. We live in the time when anything can be documented, filmed, photographed, sent and published on the social network really easily. It can be seen how media are able to react quickly to the tragic events. It occurs very often that the photograph from the place of the tragedy appears on the Internet much earlier than the family related to this case is informed. And even the situation that the mentioned families get the information about the tragedy just through the Internet is not an exception. This paper outlines the experience of the affected persons, who can read the story and the comment of different users about the tragedy that caught them personally. It is possible that published information is more or less in correspondence with the reality but the most hurting is the fact that their private details can be revealed, in many times even their intimate details. This takes part in the secondary victimization. Then the crisis intervention by the police and possible further following therapy and consultancy is more complicated.

Key words: social networks, tragic events, expiriences of the bereaved, secondary victimization, case reports 
O autorce: PhDr. Lenka Vlášková je policejní psycholožka a koordinátorka týmu pro pomoc obětem trestné činnosti Krajského ředitelství policie Pardubického kraje a zároveñ studentka doktorského studia na Filozofické fakultè Univerzity Karlovy v Praze. Zabývá se psychodiagnostickou činností, krizovou intervencí, psychickou pomocí pro obèti trestné činnosti, poradenstvím a psychologii práce a organizace, včetně lektorské činnosti. E-mail:vlaskoval@email.cz 